\title{
LITERATURA E A EXPERIÊNCIA DO ESCREVER: algumas reflexões sobre a resistência no seio da linguagem
}

\author{
Literature and the experience of writing: \\ some reflections about the resistance \\ in the heart of the language
}

\author{
Leonardo Pinto de Almeida
}

Psicólogo, Doutor em Psicologia (PUC-Rio), Pós-Doutorando PUC-Rio (bolsa PDJ/CNPq), Departamento de Psicologia, Rio de Janeiro, RJ - Brasil, e-mail: leonardo.p.almeida@gmail.com

\section{Resumo}

A partir das reflexões de Roland Barthes, Maurice Blanchot, Gilles Deleuze e Michel Foucault sobre as vicissitudes da linguagem, analisaremos o caráter transgressivo da literatura no seio da linguagem. Para tanto, partiremos da relação entre a linguagem e as palavras de ordem, mostrando a rigidez de seu uso que estaria do lado do poder, da homogeneidade, da ordem e da constância. O estereótipo e a informação são formas de atualização do ser da linguagem em seu uso costumeiro, fazendo a linguagem funcionar a partir da padronização e da noção de utilidade. No entanto, a literatura seria uma linguagem sem poder, apontando para um modo de resistir aos padrões e aos códigos linguísticos. Ela seria um modo de resistência ao fascismo da língua - uma espécie de desvio que combate o enrijecimento e o poderio da 
linguagem estereotipada. Uma luta tecida nas paragens da própria linguagem. Este entendimento da literatura como resistência aponta para ela como uma potência a serviço da vida que se contrapõe ao poder, exercido por mecanismos transcendentes à experiência. Com a literatura, as palavras tecem relações intensas e, às vezes, incomuns que proporcionam uma ruptura nos usos costumeiros da linguagem. Assim, concluímos que a literatura é uma escrita a serviço da vida em sua contraposição aos elementos transcendentes à experiência que os aprisiona em sua dinâmica de coerção e captura.

Palavras-chave: Literatura. Escrita. Experiência. Linguagem. Resistência.

\begin{abstract}
From the reflections of Roland Barthes, Maurice Blanchot, Gilles Deleuze and Michel Foucault about destines of the language, we analyzed the transgressive character of literature in the heart of the language. For in such a way, we examined the relation between the language and the words of order, having shown the rigidity of its use that would be of the side of the power, the homogeneity, the order and the constancy. The stereotype and the information are forms of update of the being of the language in its usual use, making the language to function from the standardization and of the notion of utility. However, the literature would be a language without power, indicating to resist the standards and the linguistic codes. It would be a way of resistance to the fascism of the language specie of deviation that combat the rigidity and the power of the stereotyped language. Fights weaveeed in the places of the proper language. This understanding of literature, as resistance, indicates a power in the service of life that makes opposes to the power exerted through transcendents mechanisms of experience. With literature, the words weave intense relations and, sometimes, uncommon that provide a rupture in the usual uses of the language. Thus, we concluded that literature is a writing in the service of the life in its contraposition to the transcendents elements to the experience that imprisons them in its dynamics of coercion and capture.
\end{abstract}

Keywords: Literature. Writing. Experience. Language. Resistance. 
No presente artigo, discorreremos sobre a literatura entendida, como uma linguagem transgressiva que coloca os códigos, as leis da linguagem, ou melhor, a língua - que nada mais seria do que a manifestação codificada do ser da linguagem - em questão. Acreditamos na preexistência da linguagem à vida humana. Ela, de certa forma, seria imanente à própria condição humana. Ela preexiste ao homem e determina nossa relação com as coisas e o mundo. Ela é como um mar em que, como peixes, estamos mergulhados completamente.

Assim sendo, faremos algumas considerações sobre este fato, utilizando as obras de Roland Barthes, Maurice Blanchot, Gilles Deleuze e Michel Foucault, entre outros, para traçar um modo de compreensão acerca da literatura como enlouquecimento no seio da linguagem. Para isso, deixemos claro que a linguagem é a lei indeterminada da vida e a língua o seu modo de decodificação, ou seja, o seu código.

Em $O$ rumor da língua (1984a), Barthes mostra como o homem se constitui através da linguagem, estando ele mergulhado nela, até os limites do seu ser.

O homem não preexiste à linguagem, nem filogeneticamente nem ontogeneticamente. Jamais atingimos um estado em que o homem estivesse separado da linguagem, que elaboraria então para 'exprimir' o que nele se passasse: é a linguagem que ensina a definição do homem, não o contrário (BARTHES, 1984a, p. 31-32).

Se o homem fosse definível, esta definição viria junto à compreensão do papel da linguagem. É através dela que lidamos com as coisas, com nós mesmos e com a vida. Ela preexiste ao homem, e poderíamos acrescentar: direciona as manifestações da vida humana em todas as suas peculiaridades.

Em um texto de 1873, Nietzsche, ao analisar as relações da verdade com a linguagem, argumenta da seguinte forma: “Acreditamos que sabemos alguma coisa das próprias coisas quando falamos de árvores, de cores, de neve e de flores e, no entanto, só temos metáforas das coisas, que não correspondem de forma alguma às entidades originais” (NIETZSCHE, 1873, p. 93).

Nietzsche, neste ponto de sua obra, indica que a ideia de verdade enrijece a linguagem em sua dinâmica constitutiva. Ele mostra que "as verdades são ilusões que nós esquecemos que o são, metáforas que foram usadas e que perderam a sua força sensível [...]" (NIETZSCHE, 1873, p. 94). A partir deste trecho, podemos afirmar que, em nosso dia-a-dia, há um enrijecimento do uso da linguagem. As metáforas vão perdendo sua força de troca, mostrandonos uma linguagem que caduca dela mesma. Esta caducidade da língua cotidiana, Barthes chamou de estereótipo. 
Por exemplo, quando falamos a nosso vizinho "bom dia”, esta fala se encontra enrijecida por um certo automatismo. Ela segue as fórmulas da etiqueta. Usamo-las sempre quando possível para produzir uma comunicação com nosso próximo. Neste modo de ser da linguagem, tomamo-la como um utensílio ou instrumento para um fim preestabelecido.

Outro exemplo poderia ser extraído do seguinte aspecto: uma discussão entre amigos sobre a política externa ou interna do nosso país. Este tipo de conversa, munida de verdades pessoais, preconceitos, convicções, apontam para um uso da linguagem enrijecido pela dinâmica linguageira. Os homens utilizam sentenças prontas que codificam suas convicções para se fazerem entender pelo próximo, visando significar e designar algo ao outro, tendo como objetivo o estabelecimento de uma comunicação.

No entanto, estas palavras, tomadas neste tipo de conversação, são palavras de ordem, ou, mais ainda, palavras que impõem uma ordem na seara da comunicação.

Em "20 de Novembro de 1923 - Postulados da Lingüística”, Deleuze e Guattari (1995) mostram como a dinâmica do uso social da linguagem está ligada diretamente ao uso de palavras de ordem.

As palavras de ordem não remetem, então, somente aos comandos, mas a todos os atos que estão ligados aos enunciados por uma 'obrigação social'. Não existe enunciado que não apresente esse vínculo, direta ou indiretamente. Uma pergunta, uma promessa, são palavras de ordem. A linguagem só pode ser definida pelo conjunto das palavras de ordem [...] (DELEUZE; GUATTARI, 1995, p. 15).

Deste modo, a linguagem é entendida, neste texto, como o conjunto das palavras de ordem. Isto implica uma dinâmica rígida do uso da linguagem. No entanto, estemesmo texto, ao analisar a política da linguagem, aponta para um problema que será analisado mais adiante: os usos majoritários e minoritários da língua.

O uso majoritário, o qual estaria associado diretamente com estas palavras de ordem, com a rigidez da linguagem cotidiana, com o estereótipo, implica na dominação, no poder e no metro-padrão da linguagem. Já o uso minoritário implica um modo de resistência à padronização e à rigidez da linguagem. "É por isso que devemos distinguir: o majoritário como sistema homogêneo e constante, as minorias como subsistemas, e o minoritário como devir potencial e criado, criativo” (DELEUZE; GUATTARI, 1995, p. 52). 
Poderíamos observar o seguinte: o modo de tratamento majoritário da linguagem estaria do lado do padrão, da homogeneidade, da ordem, da constância, do poder; enquanto o outro, o minoritário, seria uma via criativa que se posiciona frente ao outro uso da linguagem como uma resistência aos mecanismos de captura e controle.

Deste modo, as palavras de ordem, as convicções, os estereótipos, designam condutas, modos de pensamento impostos, visando impedir uma troca intensa que fuja dos desígnios do poder.

Assim, retornando ao argumento barthesiano, o estereótipo passa então a ser a pedra angular do uso corriqueiro da linguagem. Quando Barthes o analisa, em sua obra Roland Barthes por Roland Barthes, ele o aproxima do óbvio, da doxa, da solidez da convicção e, principalmente, do movimento de tomar como natural uma ideia.

Ele [R.B.] não conseguia sair dessa idéia sombria, de que a verdadeira violência é a do óbvio: o que é evidente é violento, mesmo se essa evidência é representada suavemente, liberalmente, democraticamente; o que é paradoxal, o que não cai sob o sentido, é menos violento, mesmo se for imposto arbitrariamente: um tirano que promulgasse leis extravagantes seria, finalmente, menos violento do que uma massa que se contentasse com enunciar o óbvio: o 'natural' é, em suma, o último dos ultrajes (BARTHES, 1975, p. 92).

A naturalização das ideias é como uma espécie de ar rarefeito no mundo da linguagem; respiramos nele, no entanto, com um certo peso a tomar nossos corpos, um certo cansaço rodeia hodiernamente o estereótipo. “O estereótipo pode ser avaliado em termos de cansaço” (BARTHES, 1975, p. 97), afirma Barthes com propriedade. Manoel de Barros, em seu livro sobre nada, apresenta uma imagem que representa perfeitamente o estereótipo: "Não gosto de palavra acostumada.” (BARROS, 1996, p. 71). Como se vê, o estereótipo aponta para uma contenção do fluxo criativo da língua, já que ele é uma maneira de cristalização dos possíveis modos de ser da linguagem. Nele está contida uma forma de língua morta, automática, caduca, cansada dela mesma, ou, para usar a expressão do poeta uma palavra acostumada. À linguagem estereotipada, Barthes (1975) contrapõe o frescor da linguagem, brisa em que é possível respirar sem a fadiga se manifestar.

Podemos também observar esta crítica ao uso corriqueiro da linguagem em uma conferência de Deleuze (2003), concedida em 1987, intitulada “Qu'est-ce que l'acte de création?.” Ao analisar o que seria a informação, ele 
marca que está, em sua natureza, a tarefa de fazer circular palavras de ordem. Estas palavras de ordem se assemelham e muito ao estereótipo barthesiano, como já assinalado antes, por elas serem mecanismos intrínsecos à linguagem, e que possibilitam o controle de seu uso.

Ainda, em "20 de Novembro de 1923 - Postulados da Lingüística," Deleuze e Guattari (1995) afirmam que estas palavras de ordem circulam na mídia por redundância.

Os jornais, as notícias, procedem por redundância, pelo fato de nos dizerem o que é 'necessário' pensar, reter, esperar, etc. A linguagem não é informativa nem comunicativa, não é comunicação de informação, mas o que é bastante diferente - transmissão de palavras de ordem. [...] (DELEUZE; GUATTARI, 1995, p. 16-17).

É curioso observarmos como o processo de redundância é um movimento de uma enorme proximidade com a palavra acostumada e o cansaço do estereótipo. Estas são duas formas de manifestação da redundância, dois lados da mesma moeda, representada por ela: o costume e o cansaço. A imposição do necessário, pelas palavras de ordem, produz hábitos, costumes linguageiros. Enquanto que esta imposição pode causar um cansaço pela repetição do pensamento acostumado.

No entanto, como seria a dinâmica da linguagem? Só existiria, deste modo, hábitos de linguagem? Qual seria a relação entre a linguagem e o poder?

Em Aula (1978), Barthes esclarece este ponto, quando assinala que a língua possui, como característica principal, um modo de ser fascista, pois determina aquilo que deve ser dito ou escrito. ${ }^{1} \mathrm{~A}$ língua já impõe uma ordem em seu modo de utilização comum.

Mas a língua, como desempenho de toda linguagem, não é nem reacionária, nem progressista: ela é simplesmente: fascista; pois o fascismo não é impedir de dizer, é obrigar a dizer. Assim que ela é proferida, mesmo que na intimidade mais profunda do sujeito, a língua entra a serviço de um poder (BARTHES, 1978, p. 14-15).

\footnotetext{
1 É possível observar, ainda, em um texto de 1973 - contido em O rumor da língua-, chamado “A divisão das linguagens “-, esta reflexão sobre o fascismo da linguagem, quando Barthes assinala que "uma língua se define não pelo que permite dizer, mas pelo que obriga a dizer” (BARTHES, 1984b, p. 120). Aqui, de novo, podemos aproximar este fascismo da língua à linguagem, entendida como conjunto de palavras de ordem.
} 
Olhando por este prisma, que assinala o fascismo constitutivo da língua, podemos aproximar o estereótipo e a informação aos domínios do poder. Estando a língua a serviço do poder, perguntemo-nos então: como devemos lidar com esse impasse? Estamos mergulhados na linguagem. Ela é imanente à vida humana. Como poderíamos fugir ao automatismo a que estaríamos supostamente condenados já que não podemos existir sem ela? Como se desvencilhar de seus domínios, se estamos cercados por ela de todos os lados? Impressão claustrofóbica com certeza, e até paranoica, apontando para uma questão realmente de difícil resolução.

A resposta barthesiana a este impasse, imposto pelo poderio da linguagem e pela nossa submissão a ele, parte do seguinte argumento: se estamos mergulhados na linguagem e, sendo ela por natureza fascista, para fugirmos ao automatismo linguageiro, ao estereótipo, devemos jogar com o fascismo da língua, trapaceando com ele. Este modo de "trapacear com a língua” (BARTHES, 1978, p. 16), Barthes chamou de literatura.

Entendo por literatura não um corpo ou uma seqüência de obras, nem mesmo um setor de comércio ou de ensino, mas o grafo complexo das pegadas de uma prática: a prática de escrever. Nela viso, portanto, essencialmente, o texto, isto é, o tecido dos significantes que constitui a obra, porque o texto é o próprio aflorar da língua, e porque é no interior da língua que a língua deve ser combatida, desviada.

A literatura seria então, um modo de resistência ao fascismo da língua - uma espécie de desvio que combate o enrijecimento e o poderio do estereótipo. Uma luta tecida nas paragens da própria linguagem. Em Le livre à venir, Blanchot afirma como Barthes que "a linguagem, no mundo, é por excelência poder” (BLANCHOT, 1959, p. 48). No entanto, ele contrapõe, à obra de arte, a lei e a obra do trabalho, afirmando não ser a arte uma linguagem que vem à luz para servir os desígnios do poder. Ela seria uma linguagem sem poder contrapondo-se à linguagem do poder - contida nos seus outros modos de manifestação. Ela não seria "a palavra útil, instrumento e meio, linguagem de ação, do trabalho, da lógica e do saber” (BLANCHOT, 1959, p. 276), característica da obra de linguagem ou da informação. Ela seria uma experiência de outro gênero, cujo atributo principal é o de ter seu fim no próprio ato de escrever.

Em um de seus textos sobre a obra de Maurice Blanchot, Lévinas (1975) expõe a diferença de natureza entre esta linguagem a serviço do poder e a linguagem sem poder, sob a égide de outra conceitualização blanchotiana: a relativa à distinção entre o dia e a noite. 
Neste artigo, chamado "Le regard du poète”, Lévinas afirma que, na obra de Blanchot, o poder, o mundo da dominação, a ação e o mundo da história estariam a serviço do dia, enquanto a arte estaria a serviço da noite. ${ }^{2}$

É interessante salientarmos a relação da consciência, da interiorização e da reflexão com as imagens de luz, de esclarecimento e, consequentemente, do dia, indicado na obra de Blanchot. Contrapondo ao pensamento ligado ao dia, poderíamos, junto a esta argumentação de Lévinas sobre os conceitos blanchotianos aqui evocados, observar que a experiência do fora, analisado no texto foucaultiano (1966), a qual rende homenagem também à obra deste autor francês, estaria do lado da noite, que provoca o questionamento e o desaparecimento das coisas, do homem e do mundo a sua volta.

Em Le livre à venir (1959), vislumbramos, através de suas páginas, esta diferença entre os desígnios do dia e da noite, marcados por este artigo de Lévinas.

Busca obscura, difícil e atormentada. Experiência essencialmente arriscada onde a arte, a obra, a verdade, e a essência da linguagem são colocadas em questão e entram em risco. [...] é a história que critica a literatura e joga o poeta de fora, colocando em seu lugar o publicitário cuja tarefa está ao serviço do dia (BLANCHOT, 1959, p. 268).

O publicitário e o crítico estariam a serviço do dia, suas palavras se submetem aos desígnios do poder, do trabalho, da utilidade. No entanto, o artista, tomado por uma busca obscura que podemos chamar, junto a Foucault, de pensamento do fora, estaria a serviço da noite, do fora, da linguagem sem poder, a qual produz palavras intensas que se contrapõem às noções de identidade, verdade, poder e utilidade.

A literatura não serve para nada e a nada. Ela está do lado da inutilidade. Mas esta seria uma inutilidade curiosa, pois a literatura não é feita para defender ideias, produzir trabalhos, convocar o povo à luta. Ela, como indica Foucault (1966), em Pensée du dehors, não serve para representar, significar atos vividos. Ela não dita regras, o que ela faz é, justamente, elaborar

2 Blanchot (1969) faz uma crítica velada ao conceito de ausência de obra, no texto "Le demain du jouer”, onde afirma ser ele uma conceitualização que serve para murar a loucura e o enlouquecimento da linguagem no espaço fechado da obra. "A ausência da obra [...] não é a loucura, mas a loucura tem o mesmo papel que a obra, já que ela permite à sociedade, como a obra, permite à literatura de reter - inofensiva, inocente, indiferente - a ausência da obra entre os limites fechados de um espaço dividido.” (BLANCHOT, 1969, p. 617). Por este motivo, em "L'absence de livre”, ele prefere utilizar o conceito de ausência do livro ao de ausência da obra. 
uma experiência intensa, promovendo transformações, nos âmbitos subjetivo e de sentido. A isso, poderíamos acrescentar que, nela, o sentir e o sentido se misturam, se colam, ressoam, no turbilhão da experiência.

Em relação a este problema da inutilidade, são inúmeras as passagens de Robbe-Grillet sobre este predicado da literatura. Em "Acerca de algumas noções obsoletas" - texto contido em Por um novo Romance -, ele argumenta que, se a literatura tem como fim ela mesma, então ela não poderia ser avaliada pelo câmbio imposto pela noção de utilidade.

Mas a necessidade por que a obra de arte se reconhece nada tem que ver com a utilidade. É uma necessidade completamente interior, que aparece evidentemente como gratuidade quando o sistema de referência é estabelecido de fora: em comparação com a revolução, por exemplo, [...], a arte mais elevada pode parecer um cometimento secundário, irrisório mesmo. Nisso está a dificuldade - íamos dizer a impossibilidade - da criação: a obra deve impor-se como necessária, mas necessária para nada; a sua arquitectura não tem uso; a sua força é inútil (ROBBE-GRILLET, 1965, p. 52).

Inutilidade constitutiva, pois na literatura o que conta éa experiência. Esta experiência, algo que tem seu fim nela mesma, não estaria a serviço do poder, ou, mais ainda, a serviço de ideias transcendentes. Ela se associaria a uma dimensão intensiva, diferente do escrever sobre, o qual se ligaria a designações, descrições, representações, em suma, a uma dimensão utilitária e funcional. Já a literatura produz um campo experiencial que nos transporta para mundos diferentes dos nossos do dia-a-dia, através de uma pluralidade de sensações. Estas sensações, promovidas, apontam para esta inutilidade estranha da literatura.

Entretanto, observemos que a apropriação da literatura feita pela cultura tende a transformá-la sob os valores da utilidade, da funcionalidade ou da informação, fazendo dela aquilo que ela não é de maneira alguma: uma obra de linguagem.

Vemos, então, que a informação, assim como as obras de linguagem, estaria do lado da comunicação e da circulação de palavras de ordem. Deleuze (2003) afirma que a obra de arte é uma contrainformação, o que faz com que se deva entendê-la como um ato de resistência. Assim, poderíamos frisar que a obra de arte e, sobretudo, a literatura estariam associadas a um combate que resiste ao poderio das palavras de ordem.

Neste ponto, Blanchot e sua afirmação, de que a literatura estaria a serviço da noite, ou ainda, que seria uma linguagem sem poder e que visaria à destruição de toda a ideia de tradição, se aproxima do entendimento deleuziano que sustenta a literatura como resistência. 
Este entendimento da literatura como resistência aponta, justamente, para a literatura como uma potência a serviço da vida que se contrapõe ao poder, exercido por mecanismos transcendentes à experiência, ou seja, desempenhado sobre a própria vida, como Deleuze (1997) assim o analisa em "A literatura e a vida".

Este componente de resistência contido na literatura aparece também na obra foucaultiana, quando ele apresenta sua análise acerca do parentesco entre a loucura e a literatura - contida nos textos "A Loucura, a Ausência de Obra” (1999a); "Loucura, Literatura, Sociedade” (1999b); e “A Loucura e a Sociedade” (1999c).

Através destes textos, Foucault examina as questões referentes aos limites sociais e linguísticos que fazem da loucura uma figura de exclusão. Porém, poderíamos nos indagar: qual seria o parentesco entre esta figura transgressiva, o louco, e a literatura?

Os mecanismos de exclusão de nossa sociedade transformaram o louco em um dos seus ícones, devido à sua linguagem transgressiva. Foucault, em “A Loucura, a Ausência da Obra” (1999a), indica alguns mecanismos de interdição e exclusão. A existência de figuras de interdição atravessa todas as sociedades, devido ao fato de que a vida humana começa, sobretudo, pelo limite e não pela liberdade. "Não há uma única cultura no mundo em que seja permitido tudo fazer. E sabemos bem, há muito tempo, que o homem não começa com a liberdade, mas com o limite e a linha do intransponível” (FOUCAULT, 1999a, p. 193).

O ultrapassamento destes limites aponta para ações transgressivas e até indesejáveis para o bom funcionamento da sociedade. Os limites existem por toda parte em que a vida se manifesta. Neste texto de 1964, Foucault distingue os limites da palavra - ou seja, da linguagem - e os dos gestos ligados obviamente ao comportamento na sociedade. Seu questionamento sinaliza para a existência de pouquíssimos estudos referentes à problemática relativa aos limites da palavra. Continuando sua argumentação, ele assinala que, no seio da linguagem, existem pelo menos quatro grupos de exclusão que perpassam todas as sociedades: os erros da língua (atividade proscrita pelo código linguístico); as palavras blasfematórias (estas palavras que deploram as interdições de articulação); as articulações que, por terem uma significação intolerável, têm seu sentido censurado; e uma linguagem esotérica que utiliza uma palavra do código num outro sentido, fazendo de sua decifração uma tarefa tecida na própria experiência comunicada. Como a loucura poderia ser entendida sob as ideias relativas aos limites e seus jogos de exclusão? Foucault é bem claro quanto a este problema, quando salienta que 
[...] a loucura é a linguagem excluída - aquela que, contra o código da língua, pronuncia palavras sem significação (os ‘insensatos', os ‘imbecis', os 'dementes'), ou a linguagem que pronuncia palavras sacralizadas (os 'violentos', os 'furiosos'), ou ainda a que faz passar significações interditadas (os 'libertinos', os ‘obstinados') (FOUCAULT, 1999a, p. 195).

A linguagem excluída da loucura se evidencia no fato de que ela transgride limites interditos pelas regras da linguagem. Em "A Loucura e a Sociedade” (1999c), Foucault ressalta que a exclusão da figura do louco perpassa domínios sociais associados diretamente à sexualidade, ao discurso, ao trabalho, às festas e aos eventos sociais em geral. Por este motivo, ela é uma figura eminentemente excluída pela sociedade.

No entanto, através de que argumento poderíamos aproximar a literatura e a loucura? Antes de tudo, a loucura e a literatura são atualizações do ser da linguagem. Muito bem, poder-se-ia concordar, e apontar que a loucura é uma linguagem excluída, diferentemente da literatura. Porém, neste texto de 1970, Foucault mostra que a literatura seria uma linguagem anárquica, marginal, transgressiva, que foge às regras da linguagem cotidiana. Neste ponto, observemos a proximidade estreita entre as críticas - formuladas por Foucault, Blanchot, Barthes e Robbe-Grillet - ao uso corriqueiro da linguagem, apostando na resistência da literatura aos modos enregelados da fala estereotipada. O parentesco da literatura com a loucura mostra "que há uma curiosa afinidade entre a literatura e a loucura. A linguagem literária não está obrigada às regras da linguagem cotidiana” (FOUCAULT, 1999c, p. 239).

Esta oposição - assinalada pelos quatro autores supracitados entre a linguagem cotidiana e a linguagem transgressiva corrobora a aproximação entre loucura e literatura. Ambas resistem, transgridem as regras comumente empregadas no uso da linguagem e aceitas no dia-a-dia. No entanto, este potencial transgressivo da literatura - observa Foucault, em "A Loucura e a Sociedade” (1999c) - tem sido progressivamente solapado pela força intrínseca de adaptação e absorção do capitalismo. Em outra ocasião, apontamos (2002) que este processo é uma espécie de pasteurização da transgressão. O impacto transgressivo da literatura - característico da época em que ela emergiu - tem sido absorvido por mecanismos que visam transformar a experiência total da literatura em moedas de troca no mundo da utilidade, ou seja, transformá-la em uma obra de linguagem ou uma informação.

Podemos observar sem muita dificuldade que a linguagem transgressiva garante a constituição desta forte ligação entre loucura e literatura. No entanto, elas diferem entre si num ponto bastante claro aos 
nossos olhos: a loucura é uma linguagem transgressiva excluída da sociedade; já na literatura, vemos uma linguagem que transgride os liames da linguagem, mas é aceita no interior do domínio social. Aproximamos então as duas para perceber as peculiaridades de cada uma, diferindo-as novamente, mas sob uma nova camada de entendimento. Foucault, em "A Loucura, a Ausência da Obra” (1999a), prossegue em seu estudo destas duas linguagens transgressivas distinguindo-as, neste momento, através da oposição entre obra e ausência de obra. A loucura é transgressiva, mas, ao contrário da literatura, ela nada constrói, ela não se torna obra.

Tanto loucura quanto literatura estão ligadas às questões relativas à transgressão e ao limite. Ambas rompem com os limites nos domínios da linguagem. A literatura é disruptora, tendo como característica principal o rompimento com os seus próprios limites. Porém, em seu movimento criativo, ela institui novos limites sobre o corpus da obra literária. A ruptura produzida em seu movimento transgressivo não é, de maneira alguma, total, pois, como vemos, ela funda a obra. Já a loucura se dá como uma ruptura total que não se materializa em obra, não restitui os limites após a transgressão se manifestar; ela supostamente não constrói nada. Ela é pura transgressão, não constituindo nem um passado nem um futuro, ela seria a forma vazia do movimento transgressivo. Por isso, Foucault diz ser ela a ausência da obra.

[...] a loucura não manifesta nem relata o nascimento de uma obra [...]; ela designa a forma vazia de onde vem essa obra, quer dizer o lugar de onde ela não cessa de estar ausente, no qual jamais a encontramos porque jamais ela aí se encontrou (FOUCAULT, 1999a, p. 197).

Esta forma vazia aponta para o entendimento de que a natureza da obra está aparentada com a loucura, pois se nutre, de alguma maneira, dela no movimento transgressivo.

Blanchot, no artigo “L'absence de livre” - contido em L'Entretien Infini (1969) -, faz algumas reflexões pertinentes sobre a ausência da obra. Ele afirma que: "Escrever é produzir a ausência da obra (o désœuvrement). Ou ainda, escrever é a ausência da obra, tal como ela se produz através da obra atravessando-a” (BLANCHOT, 1969, p. 622).

A ausência de obra seria esta forma vazia que atravessa a experiência literária na produção da obra. Para Blanchot, a criação literária passa por este désœuvrement. Isto significaria que a obra literária nasce deste movimento produzido através de uma "atração da ausência da obra" (BLANCHOT, 1969, 
p. 624). Que nada mais seria do que a atração do fora (FOUCAULT, 1966). Atração que seria o contato radical com o vazio da morte no seio da linguagem. ${ }^{3}$ Esta experiência de uma obscuridade singular, Foucault (1966) designou-a como pensamento do fora, contrapondo-a ao pensamento reflexivo.

“ $\mathrm{O}$ ‘tema’ da literatura (esse que fala nela e esse do qual ela fala) não seria propriamente a linguagem em sua positividade, mas o vazio onde ela acha seu espaço quando ele se anuncia na nudez do 'eu falo'” (FOUCAULT, 1966, p. 525).

Esta experiência de acolhimento do "lugar vazio onde fala o désœuvrement." (BLANCHOT, 1959, p. 290) seria, evidentemente, o pensamento obscuro que Foucault (1966), através de sua reflexão sobre a obra blanchotiana e a experiência moderna, chamou de pensamento do fora.

A literatura então seria um encontro com este vazio, designado, aqui, pelos termos de ausência da obra e désœuvrement.

No entanto, voltemos ao texto foucaultiano de 1964: "A loucura, a Ausência de Obra” (1999a). Neste artigo, Foucault retoma a distinção entre obra de linguagem e literatura - diferenciação analisada também nos textos "A Linguagem ao Infinito" (2001) e "Linguagem e Literatura”. (2000). Ele salienta que a produção de uma obra de linguagem se daria sobre uma "língua dada" (FOUCAULT, 1999a, p. 196) e, assim, haveria um princípio de decifração preexistente à experiência de sua escrita.

Por ser a obra de linguagem, como já observamos, fruto de uma revelação ou a restituição de uma fala transcendente à experiência, o encontro com ela se basearia em pôr a revelação em jogo, através de um principio de decifração atrelado a elementos exteriores e transcendentes a este evento. Este princípio estaria, assim, associado a esta fala antecedente, a esta fala dada, ao já-dito de uma certa tradição.

Já a literatura teria seu próprio princípio de decifração. Sobre este assunto, Robbe-Grillet afirma, em "Para que servem as teorias": “cada romancista, cada romance, deve inventar a sua própria forma. Nenhuma receita pode substituir esta reflexão permanente. O livro cria só para si as próprias regras.” (ROBBEGRILLET, 1965, p. 13) A literatura inventa uma teia de relações, constituindo

3 Blanchot (1969) faz uma crítica velada ao conceito de ausência de obra, no texto "Le demain du jouer”, onde afirma ser ele uma conceitualização que serve para murar a loucura e o enlouquecimento da linguagem no espaço fechado da obra. "A ausência da obra [...] não é a loucura, mas a loucura tem o mesmo papel que a obra, já que ela permite à sociedade, como a obra, permite à literatura de reter - inofensiva, inocente, indiferente - a ausência da obra entre os limites fechados de um espaço dividido.” (BLANCHOT, 1969, p. 617). Por este motivo, em "L’absence de livre", ele prefere utilizar o conceito de ausência do livro ao de ausência da obra. 
suas próprias regras. Entendida como uma linguagem transgressiva, ela se apresenta como uma atividade cujo caráter principal é o de usar palavras comuns no uso cotidiano, inserindo-as, no entanto, em uma rede diferente de relações.

É como se a escrita literária fosse uma escrita insolente que sabotasse a linguagem. Ela faz as palavras se metamorfosearem, tecendo relações intensas e, às vezes, incomuns, que proporcionam uma ruptura com os usos costumeiros da linguagem. Por isso, sua decifração será somente posta em jogo na própria experiência literária.

Deste modo, podemos afirmar que a decifração da obra está nela mesma, na forma de experienciá-la, e não fora de seu mundo. A literatura constrói mundos com regras próprias, elaborando uma experiência que indica a não existência de princípios de decifração exteriores à sua experimentação. De maneira que o parentesco com a loucura agora se evidencia, pois ambas tem seu próprio princípio de decifração fundado na experiência, e não fora dela.

Em "Loucura, Literatura, Sociedade” (1999b), Foucault afirma ser a literatura uma "subversão escrita” (FOUCAULT, 1999b, p. 220), a qual transgride certas regras lingüísticas, subvertendo a escrita. Devido a esta subversão, Foucault conclui que "é normal que os escritores encontrem seu duplo no louco ou em um fantasma”. (FOUCAULT, 1999b, p. 220)

A atividade transgressiva característica da literatura tem, como modelo, a loucura. É como se fazer literatura fosse enlouquecer a escrita, subverter, desmoronar, romper, transgredir, contestar os limites impostos pela própria linguagem. A literatura não constitui uma tradição, não leva em conta uma tradição literária anterior ao ato da escrita, ela tem seu início no próprio escrever, entendido aqui como uma recusa ao já-dito. Não há nada anterior ao seu ato, por isso a chave para a decifração de seus enunciados está neles próprios. O louco é um exemplo para o escritor, no sentido de que aquele remete a uma figura, eminentemente transgressiva, que não possui nenhum passado. Se a verdade da obra literária está na atividade transgressiva da escrita, a loucura torna-se, então, modelo para ela, caracterizando o seio de onde a obra pode brotar. É desse vazio transgressivo, representado pela loucura - essa ausência de obra -, que pode emergir a literatura, entendida como subversão.

Sobre isso, podemos retomar o désœuvrement blanchotiano encontrado, em L'Entretien Infini (1969), e aproximá-lo ao desmoronamento referido em A parte do fogo (1997). Blanchot afirma ser a literatura fruto de um desmoronamento no seio da linguagem. É como se o muro de contenção representado pelo estereótipo desmoronasse para dar lugar a um outro modo de tomar a palavra através da escrita. 
Mas ela [a literatura] pressupõe um desmoronamento, uma espécie de catástrofe inicial e o próprio vazio medido pela angústia e preocupação, sim, podemos afirmá-lo. Só que, vale notar, essa catástrofe não se abate unicamente sobre o mundo, os objetos que manipulamos, as coisas que vemos; ela se estende também à linguagem (BLANCHOT, 1997, p. 72-73).

Catástrofe que se estende à linguagem. Karl Kraus tem um aforismo que representa bem esta catástrofe que produz a criação literária: "Só uma língua que tem câncer tende a novas formações.” (KRAUS, 1988, p. 114) Câncer da língua, desmoronamento da linguagem, estas são imagens interessantes para pensarmos a questão da literatura.

Trapaça, subversão, enlouquecimento da linguagem, estes são alguns sinônimos da escrita transgressiva - a literatura -, que se contrapõe aos códigos comuns do uso linguageiro. Em Crítica e Clínica (1997), Deleuze coaduna com esta ideia ao examinar o ser da literatura e sua relação com aquilo que chamou de minorar a língua.

Ao apresentar o problema que atravessa todo este livro, Deleuze analisa também a relação entre loucura (delírio) e literatura. Ele assinala que tanto a literatura quanto a loucura seriam "acontecimentos na fronteira da linguagem” (DELEUZE, 1997, p. 9).

A literatura seria uma espécie de delírio: fazer delirar a língua. Esta é a natureza da literatura. A literatura é um convite a delirar com o seu espaço experiencial, através de um ato insolente que sabota os códigos da linguagem.

Rememorando aquilo que, em Contre Sainte-Beuve (1954), Proust sublinhou com tanta propriedade sobre a experiência escrita, Deleuze apresenta a relação do escrever com este delírio:

O problema do escrever: o escritor, como diz Proust, inventa na língua uma nova língua, uma língua de algum modo estrangeira. Ela traz à luz novas potências gramaticais e sintáticas. Arrasta a língua para fora de seus sulcos costumeiros, leva-a a delirar. (DELEUZE, 1997, p. 9).

Delírio no seio da linguagem, contraposição aos códigos comumente usados por nós no cotidiano. A literatura, entendida desta forma, aponta para uma crítica à linguagem majoritária e fascista intrínseca ao seu uso comum.

No entanto, o delírio, quando descamba para um estado clínico, nada cria, ele seria a doença, enquanto a literatura a saúde. Poderíamos, aqui, aproximar a análise foucaultiana acerca da obra e da ausência de obra. Enlouquecer, fazer delirar a língua produzindo obra, esta seria a literatura. Uma 
espécie de remédio para a esclerose da linguagem estereotipada. No entanto, quando o delírio se perde nele mesmo, aponta para a ausência de obra, ou, dito de outro modo, para um estado clínico.

Em “A literatura e a vida”, texto contido em Crítica e Clínica Deleuze (1997), relaciona o delírio observado no ato da escrita literária e o minorar a língua. Escrever literatura seria enlouquecer a tal ponto a linguagem fazendo com que ela subverta os códigos majoritários de seu uso. Por isso, ele diz, com Proust, que fazer literatura é escrever em uma língua estrangeira.

O que a literatura produz na língua já aparece melhor: como diz Proust, ela traça aí precisamente uma espécie de língua estrangeira, que não é uma outra língua, nem um dialeto regional redescoberto, mas um devir-outro da língua, uma minoração dessa língua maior, um delírio que a arrasta, uma linha de feitiçaria que foge ao sistema dominante. (DELEUZE, 1997, p. 15).

Minorar a língua seria, então, produzir uma forma de crítica à língua materna, maior e dominante, cavando vias de escoamento com o intuito de transgredir os limites impostos pela linguagem. Ao analisar este problema no sexto capítulo de Crítica e Clínica, Deleuze afirma que "uma literatura de minoria não se define por uma língua local que lhe seria própria, mas por um tratamento a que ela submete à língua maior.” (DELEUZE, 1997, p. 66) Ou seja, o que caracterizaria a literatura e sua forma de minorar a língua seria 0 modo como ela trata a língua dominante.

Em “20 de Novembro de 1923 - Postulados da Lingüística”, depois de apresentarem as palavras de ordem, Deleuze e Guattari (1995), à luz ainda da referência proustiana, apresentam a natureza deste embate com a língua maior, afirmando que escrever literatura é o mesmo que ser gago da linguagem, ou ainda, ser estrangeiro na própria língua.

É a mesma coisa que gaguejar, mas estando gago da linguagem e não simplesmente da fala. Ser um estrangeiro, mas em sua própria língua, e não simplesmente como alguém que fala uma outra língua, diferente da sua. Ser bilíngüe, multilíngüe, mas em uma só e mesma língua, sem nem mesmo dialeto ou patuá. (DELEUZE; GUATTARI, 1995, p. 42-43).

Neste caso, a palavra transgressão seria atrapalhada por significações que talvez impeçam entender esta dinâmica do embate empenhado pela literatura menor. A minoração da língua não seria a feitura de uma ferida ou um forte golpe na língua maior, ela estaria mais para uma sabotagem ou uma gagueira. 
A ideia da literatura menor é mais bem desenvolvida no livro de Deleuze e Guattari sobre Kafka. Neste livro, as teses, apresentadas em Crítica e Clínica e em "20 de Novembro de 1923 - Postulados da Lingüística” são fundamentadas com mais afinco.

A tese do uso intensivo e do tratamento estrangeiro da língua maior está relacionada à minoração da língua. $\mathrm{O}$ minorar a língua muito se parece com o desmoronamento da linguagem em Blanchot. Em "O paradoxo de Aytré", Blanchot (1997), ao comentar o texto de Paulhan "Aytré qui perd l'habitude”, mostra como a experiência literária pode ser desconcertante de certa forma, já que a escrita literária surge primeiramente de um desmoronamento da linguagem, isto é, de um desmantelamento dos usos rígidos que serviriam para descrever e designar as coisas com objetividade. O poeta e sua obra emergem em um contato incomum com a língua maior. A linguagem é levada a se perder em sua rigidez para que suscite sensações e, através da inutilidade da literatura, elabore experiências intensas que façam sentido somente por elas mesmas.

Este uso menor da língua aponta para o escrever com. O uso menor da língua escreve com o escrever e com a língua maior, dando-lhe destinos incomuns e usos estranhos aos costumes linguageiros. Nisto, ela é de um caráter revolucionário. Gaguejar, sabotar, usar de forma estrangeira a língua maior, tais seriam os desígnios da literatura menor.

Mas, isto que é ainda mais interessante é a possibilidade de fazer de sua própria língua, ao supor que ela seja única, que ela seja uma língua maior ou que a tenha sido, um uso menor. Ser na sua própria língua um estrangeiro. (DELEUZE; GUATTARI, 1975, p. 48).

No texto de Paulhan, comentado por Blanchot (1997), Aytré usufruía a linguagem comum para descrever os acontecimentos dos trabalhos militares a que se submetia. No entanto, há uma reviravolta na sua atividade de escrever seus relatórios: ele sente sua linguagem desmoronar e, a partir de então, passa a escrever belas sentenças que fogem aos costumes de sua atividade de descrição. Deste modo, através do desmoronamento da linguagem e, por conseguinte, da perda de domínio sobre esta - tão comum à seara da descrição -, a sua escrita, que era um escrever sobre os acontecimentos do dia, passa a ser um escrever com a própria linguagem.

Assim podemos apontar que esta estrangeiridade, salientada por Deleuze e Guattari, é sentida pelo militar Aytré, quando sua linguagem objetiva, usada na escrita de seus relatórios de campo, é atravessada por usos incomuns, retirando a segurança que a rigidez da linguagem a serviço da descrição e da designação lhe proporcionavam. 
Quando Deleuze e Guattari (1975) se indagam sobre as características da literatura menor, chegam à conclusão de que ela possui três características principais: a literatura menor é atravessada por um coeficiente de desterritorialização, pela política e por um valor coletivo.

A desterritorialização, aqui, poderia ser entendida como uma intensidade que faz com que a língua maior seja sabotada em seus códigos e suas regras intrínsecas, desfazendo algumas de suas rígidas relações que poderíamos chamar de territórios discursivos.

Esta sabotagem da língua é sempre cotejada com uma dimensão política - uma recusa às tradições, aos costumes da língua maior e assim por diante. No entanto, esta dimensão política, por ser uma experiência que foge à dinastia da representação e da interiorização da história e do mundo, experiência que Foucault (1966) chamou muito propriamente de pensamento do fora; se quer impessoal, ou melhor, supra-pessoal ou coletiva.

Neste contexto podemos salientar que o uso menor da língua maior é um ato de resistência e, por conseguinte, revolucionário. "Igualmente podemos dizer que 'menor' não qualifica mais algumas literaturas, mas as condições revolucionárias de toda literatura no seio disto que chamamos grande (ou estabelecida)” (DELEUZE; GUATTARI, 1975, p. 33).

Assim sendo, a minoração da língua caracterizaria este potencial transgressivo, de trapaça, de sabotagem, de resistência, intrínsecos à experiência do escrever literário.

Através desta reflexão, podemos concluir que, como a loucura e a literatura em Foucault criam seu próprio código de decifração ao surgir, na obra deleuziana, o uso menor da língua não preexiste à língua dominante, ela emerge deste embate, deste modo de fazer delirar a língua. Poderíamos assim afirmar que a literatura é um modo de resistência à qualquer ideia de tradição, ou seja, à qualquer ideia transcendente ao seu campo experiencial, apontando para um modo de tratamento da linguagem que foge aos padrões e às paragens da utilidade e da funcionalidade: Ela seria um modo de atualização do ser da linguagem que indica uma maneira de lidar com a língua maior, padrão, visando a trapaça, o delírio e a contraposição ao domínio e ao controle derivados diretamente da língua materna, ou seja, a minoração da língua. Assim, esta minoração seria, justamente, este potencial de resistência que faz da literatura uma escrita a serviço da noite e do fora, uma potência a serviço da vida em sua contraposição aos elementos transcendentes à experiência que os aprisiona em sua dinâmica de coerção e captura. 


\section{REFERÊNCIAS}

ALMEIDA, L. O problema da autoria: internet, literatura e ontologia. 2002. $349 \mathrm{f}$. Dissertação (Mestrado em Estudos da Subjetividade) - Universidade Federal Fluminense, Rio de Janeiro, 2002.

BARROS, M. O livro sobre o nada. Rio de Janeiro: Record, 1996.

BARTHES, R. Roland Barthes por Roland Barthes. São Paulo: Cultrix, 1975.

. Aula inaugural da cadeira de semiologia literária do Colégio de França, pronunciada dia 7 de janeiro de 1977. São Paulo: Cultrix, 1978.

Escrever, verbo intransitivo? In: O rumor da língua. São Paulo: Brasiliense, 1984a. p. 30-39.

. A divisão das linguagens. In: O rumor da língua. São Paulo: Brasiliense, 1984b. p. 110-122.

BLANCHOT, M. Le livre à venir. Paris: Gallimard, 1959.

L'entretien infini. Paris: Gallimard, 1969.

A parte do fogo. Rio de Janeiro: Rocco, 1997.

DELEUZE, G. Crítica e clínica. Rio de Janeiro: Ed. 34, 1997.

. Qu'est-ce que l'acte de création? In:

. Deux régimes de fous: textes et entretiens, 1975-1995. Paris: Les Éditions de Minuit, 2003. p. 291-302.

DELEUZE, G.; GUATTARI, F. Kafka, pour une littérature mineure. Paris: Les Éditions de Minuit, 1975.

20 de Novembro de 1923 - Postulados da Lingüística. In: Mil Platôs, capitalismo e esquizofrenia. Rio de Janeiro: Ed. 34, 1995. v. 2, p. 11-59.

FOUCAULT, M. La pensée du dehors. In: . Revue critique. Maurice Blanchot. Paris: Editions de Minuit, 1966. p. 533-546. Tomo XXII, n. 229.

A loucura, a ausência da obra. In: Ditos e escritos I. problematização do sujeito: psicologia, psiquiatria e psicanálise. Rio de Janeiro: Forense Universitária, 1999a. p. 190-198. 
Loucura, literatura, sociedade. In: Ditos e escritos I.

problematização do sujeito: psicologia, psiquiatria e psicanálise. Rio de Janeiro: Forense Universitária, 1999b. p. 210-134.

A loucura e a sociedade. In:

Ditos e escritos I. problematização do

sujeito: psicologia, psiquiatria e psicanálise. Rio de Janeiro: Forense Universitária, 1999c. p. 235-242.

Linguagem e literatura. In: MACHADO, R. Foucault, a filosofia e a literatura. Rio de Janeiro: JZE, 2000. p. 137-174.

A linguagem ao infinito. In:

. Ditos e escritos III. estética: literatura e pintura, música e cinema. Rio de Janeiro: Forense Universitária, 2001. p. 47-59.

KRAUS, K. Ditos e desditos. São Paulo: Brasiliense, 1988.

LEVINAS, E. Le regard du poète. In: . Sur Maurice Blanchot. Paris: Fata Morgana, 1975.

NIETZSCHE, F. Introdução teorética sobre a verdade e a mentira no sentido extramoral. In: . O livro do filósofo. Lisboa: Rés, 1873. p. 89-109.

PROUST, M. Contre sainte-beuve. Paris: Gallimard, 1954.

ROBBE-GRILLET, A. Por um novo romance. Lisboa: Publicações Europa-América, 1965.

Recebido: 27/11/2008

Received: $11 / 27 / 2008$

Aprovado: $15 / 12 / 2008$

Approved: $12 / 15 / 2008$

Revisado: 02/10/2009

Reviewed: 10/02/2009 